\title{
REVIEW
}

\section{Interactive effects of nutrient supply and other environmental factors on the sensitivity of marine primary producers to ultraviolet radiation: implications for the impacts of global change}

\author{
John Beardall ${ }^{1, *}$, Slobodanka Stojkovic ${ }^{1}$, Kunshan Gao ${ }^{2}$ \\ ${ }^{1}$ School of Biological Sciences, Monash University, Clayton, Victoria 3800, Australia \\ ${ }^{2}$ State Key Laboratory of Marine Environmental Science, Xiamen University, 361005 Xiamen, PR China
}

\begin{abstract}
Understanding the effects of global climate change on the algae that form the basis of most aquatic food chains is of paramount importance in our ability to make informed decisions about the future of production systems, marine ecosystems, and the global carbon cycle. Despite the Montreal Protocol to restrict the release of harmful chlorofluorocarbons into the atmosphere, ozone levels have not recovered at all latitudes, and in some regions levels of UVB are still rising due to interactions with phenomena related to climate change. However, the effects of UV radiation may be modulated by other environmental changes. In this review, we discuss how factors such as elevated $\mathrm{CO}_{2}$ and ocean acidification, increasing temperature, and reduced nutrient supply associated with enhanced stratification can interact with UV radiation to affect algal physiological performance and growth. For instance, nutrient limitation enhances UV-induced inhibition due to the reduced capacity of algae to screen out UVB and/or impairment of their capacity to repair damage. Higher temperatures tend to promote repair more than photochemical damage so result in a net reduction of UV inhibition. Elevated $\mathrm{CO}_{2}$ and ocean acidification has complex interactions with UV radiation, with mixed net outcomes for algal productivity. Differential effects of UVA and UVB have been shown to depend on their irradiance levels; while moderate levels of UVA stimulate growth and photosynthesis of some algae, UVB almost always results in harm to marine primary producers.
\end{abstract}

KEY WORDS: UV radiation ' Algae - Global climate change · Ocean acidification . Nutrient limitation · Temperature

\section{INTRODUCTION}

We are living in a time in which changes in the global environment are occurring at a rate unsurpassed in geological history. These changes will see atmospheric $\mathrm{CO}_{2}$ rise to $\sim 1000 \mathrm{ppm}$ by the end of this century (Meehl et al. 2007). This will lead to an average increase in global temperature of $\sim 4^{\circ} \mathrm{C}$ (Pachauri \& Reisinger 2007) and result in more $\mathrm{CO}_{2}$ being dissolved in the oceans, making them more acidic and

\footnotetext{
${ }^{*}$ Corresponding author: john.beardall@monash.edu
}

altering seawater carbonate chemistry (Feely et al. 2009). Furthermore, modelling suggests that, given the right balance between wind stress and surface heating, higher temperatures will lead to more intense stratification, which will reduce the upward transport of nutrients from deeper waters (Doney et al. 2012). Models of such a scenario though are still sensitive to a number of assumptions, though some data support the predictions (Goffart et al. 2002). The anthropogenic release of chlorofluorocarbons and

(C) The authors 2014. Open Access under Creative Commons by Attribution Licence. Use, distribution and reproduction are unrestricted. Authors and original publication must be credited. 
other active compounds into the atmosphere causes the breakdown of ozone in the stratosphere and this leads to a rise in the fluxes of UVB transmitted to Earth's surface. This is most marked at (but is not exclusive to) high latitudes (Hegglin \& Shepherd 2009). Increased global warming, which leads to enhanced cooling in the stratosphere, also has implications for ozone depletion and the consequent increases in UVB incident on the surface of the oceans, though new models take into account a wide range of forcings (Watanabe et al. 2011). The ozone layer is expected to show a gradual recovery in years to come (McKenzie et al. 2011), though this is complex and depends, inter alia, on latitude and greenhouse gas emissions (Williamson et al. 2014).

UVR has a range of inhibitory effects on the physiological activities of algae. These include inhibition of nutrient uptake, damage to DNA, and damage to light transduction and carbon assimilation mechanisms. UVR is also known to affect morphogenesis of photosynthetic organisms and different wavelength ranges (UVA and UVB) can have different effects. Thus, UVB has been shown to break the spiral filaments of Arthrospira platensis and compress or tighten its helix (Wu et al. 2005, Gao et al. 2008), while in the red alga Porphyra haitanensis, UVA enhanced the formation of sporelings with cells dividing transversely, whereas UVB delayed the formation of such sporelings (Jiang et al. 2007). UVB also has impacts on aspects of the reproductive biology of macroalgae (Wiencke et al. 2000). While the effects of UVB are nearly always detrimental, there are reports of positive effects of UVB on recovery from photoinhibition and stimulation of photoprotection mechanisms (Pérez-Rodríguez et al. 1998, 2001, Flores-Moya et al. 1999, Figueroa et al. 2002, Hanelt et al. 2006, Hanelt \& Roleda 2009). Viñegla et al. (2006) reported enhancement of carbonic anhydrase and nitrate reductase activities of the macroalgae Fucus spiralis and Ulva olivascens under UVR exposure. Such positive and negative effects are well documented and the reader is referred to the excellent reviews by Vincent \& Neale (2000), Buma et al. (2003), Häder \& Sinha (2005) and Häder et al. (2007).
UVB-induced damage can be reduced by intracellular compounds such as mycosporine-like amino acids (MAAs), which screen out UVB and UVA (Carreto \& Carignan 2011), or by the activity of a range of defence mechanisms, involving enzymes, such as ascorbate oxidase and superoxide dismutase, involved in scavenging reactive oxygen species (ROS). Algae are also capable of repairing any damage incurred, though this comes at a metabolic cost. Acclimation to solar UVR can also occur and the reader is directed to the reviews of Figueroa \& Gómez (2001) and Bischof et al. (2006) for details.

UVB does not affect algal performance in isolation, but interacts with a host of other environmental factors that govern the overall impacts of global change. It is becoming apparent that a full understanding of the impacts of global change on oceanic biota will only come with an appreciation of the complex interactions between environmental parameters (Boyd \& Hutchins 2012). Some of these interactions are summarized in Fig. 1.

A future ocean, for example, will see algae exposed to higher levels of $\mathrm{CO}_{2}$ and ocean acidification, and warmer surface waters, which, in open oceans at least, are predicted to lead to lower nutrient availability due to shoaling of the upper mixed layer (UML) (Doney et al. 2012). For phytoplankton, changes in water column structure will mean that these organisms will be exposed to higher average

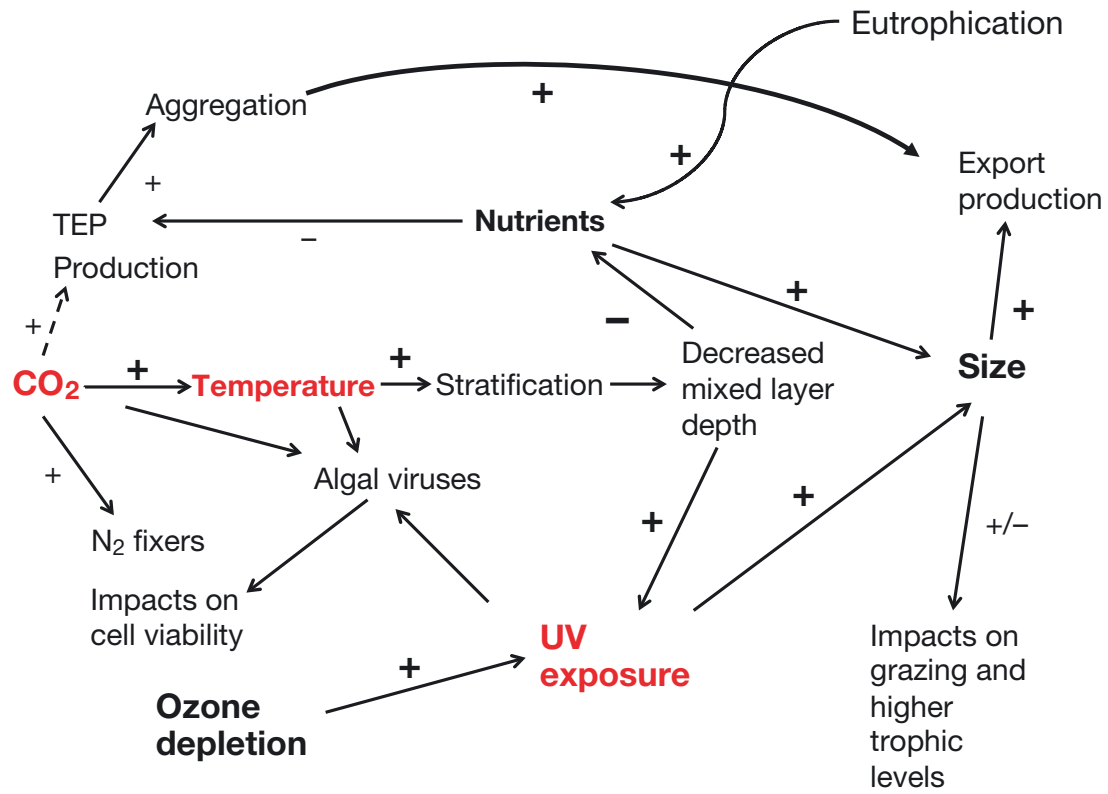

Fig. 1. Schematic of some of the complex interactions between parameters associated with global change and their effects on algal performance. TEP: transparent exopolymer. Factors in red are primary aspects of global change; those in bold black are secondary consequences. +: positive effect, -: negative effect 
fluxes of photosynthetically active radiation (PAR) and UVR as they circulate in a shallower mixed layer, and both phytoplankton and benthic algae will be subjected to higher UVB doses associated with ozone depletion. At higher latitudes, phytoplankton are often light-limited; a reduced depth of the UML (and reduced ice and snow cover) would allow phytoplankton cells to receive increased light exposures closer to the surface, so their growth may become stimulated. Climate warming and the resultant loss of snow and ice cover is likely to have a dramatic impact on UV penetration of polar seas (Vincent \& Belzile 2003)

As mentioned above, ocean warming associated with global warming is predicted to lead to enhanced stratification and consequent increased severity of nutrient limitation in the UML of temperate and tropical waters (Doney 2006). Decreased nutrient levels in the open ocean will favour smaller-celled organisms, which will impact on grazing rates as well as on sinking rates into the deep ocean and the strength of the biological $\mathrm{CO}_{2}$ pump (Finkel et al. 2010). Running counter to this is the tendency for elevated $\mathrm{CO}_{2}$ to lead to increased production of transparent exopolymers by phytoplankton (Engel 2002, Engel et al. 2004). These will, inter alia, promote aggregation and might then enhance sinking rates. Increased partial pressure of $\mathrm{CO}_{2}\left(p \mathrm{CO}_{2}\right)$ and consequent ocean acidification (OA) also influence factors such as calcification (though this is contentious in some cases (Riebesell et al. 2000, Orr et al. 2005, Langer et al. 2006, Iglesias-Rodriguez et al. 2008)) and cell size. $\mathrm{OA}$ is likely to influence the 'rain ratio' (the ratio of $\mathrm{CaCO}_{3}$ to organic carbon in the continuous 'rain' of biogenic particles that sink down from the ocean's surface) (Beaufort et al. 2011, Hutchins 2011). OA is also known to affect elemental ratios (Finkel et al. 2010, Riebesell \& Tortell 2011).

What then are the consequences of these changes, especially in regards to the interactions between UVB and other environmental factors? In terms of both PAR and UVR, for phytoplankton, there are implications for cell size and the size structure of communities. As discussed by Finkel et al. (2010), changes in the light environment resulting from climate change-induced stratification are likely to have important consequences for the susceptibility of different-sized phytoplankton to UVR- and PARinduced damage. Cell size-related differences in the susceptibility to photodamage, and in rates of repair, have been reported from both field samples and laboratory cultures (Karentz et al. 1991, Laurion \&Vincent 1998, Key et al. 2010) and shifts in the light regime associated with climate warming will alter phytoplankton community size structure (MacIntyre et al. 2000, Beardall \& Raven, 2004, Six et al. 2007). Thus small cells would be favoured under lightlimiting environments, but large cells are advantaged under high PAR (Key et al. 2010) and high UVR conditions (Raven 1991). Small cells are more susceptible targets for photoinhibitory (PAR and UVR) radiation and may be unable to accumulate enough UV-absorbing compounds to shield the UV-sensitive cellular components, such as D1 protein and Rubisco (Raven 1991, Garcia-Pichel 1994). In situ photosynthetic carbon fixation measurements show less UVinduced inhibition in coastal than in pelagic waters, reflecting differential responses of phytoplankton assemblages with a greater proportion of larger cells in the former compared with the latter (Li et al. 2011). Further discussion of the relationship between UVR sensitivity and cell size may be found in Villafañe et al. (2003) and Finkel et al. (2010).

However, lower nutrient levels favour smaller-celled organisms, such as the picoplanktonic cyanobacterium Prochlorococcus or, among the eukaryotes, picophytoplankton such as Micromonas and Ostreococcus and nanophytoplankton including coccolithophorids such as Emiliania huxleyi. W. K. W. Li et al. (2009) have recently reported shifts towards smaller phytoplankton taxa in Arctic surface waters associated, inter alia, with decreased nitrate levels. Nutrient supply and concentration in the UMLs of the oceans are frequently significant drivers of variation in the size structure and taxonomic composition of phytoplankton communities (Eppley \& Peterson 1979, Chisholm 1992, Coale et al. 1996, Finkel et al. 2010). A shift towards smaller phytoplankton species increases photosynthetic light use efficiency (Taguchi 1976), decreases productivity, and leads to changes in the size structure of pelagic and benthic food webs and the magnitude of carbon export to the deep ocean (Pomeroy 1974, Smith et al. 1997, Finkel 2007, Finkel et al. 2010). A full discussion of the interactions between the cell size of phytoplankton and environmental factors can be found in Finkel et al. (2010).

Thus, surface waters in a future ocean will see a greater proportion of smaller phytoplankton with less UVB screening capacity. These cells will be subjected to increased nutrient stress and, with shallower mixed layers, higher integrative exposures to PAR as well as UVA and UVB irradiances, which could influence the cells periodically, acutely, or persistently, depending on hydrological dynamics in different oceanic environments. Exposure to UVR and PAR will also depend on the bio-optical proper- 
ties of the water column, though these can be complex and quite varied between sites. For example, decreased turbidity of seawater in regions of the Bay of Biscay led to increased UV penetration with impacts on the physiological performance of the red alga Gelidium corneum (Quintano et al. 2013). Phytoplankton in waters with faster mixing rates exhibit different responses to UVA and UVB irradiances compared with those in less mixed or static conditions (Helbling et al. 2003, Jin et al. 2013, Li et al. 2013). Faster mixing or fluctuation of solar radiation led to less UV-induced inhibition of photosynthetic carbon fixation (Helbling et al. 2003), and a shallower mixing depth led to higher UVA and UVB inhibition of photosynthetic carbon fixation ( $\mathrm{Li}$ et al. 2013) of phytoplankton assemblages of coastal waters. Furthermore, the coccolithophorid Gephyrocapsa oceanica showed much lower non-photochemical quenching under fluctuating light regimes (mimicking rapid mixing) than under static constant light levels (Jin et al. 2013).

In near-shore coastal waters, however, models suggest greater storm activity with increased water turbulence and runoff, leading to enhanced nutrient loads (Bakun 1990, Rabalais et al. 2002). This in turn may lead to dominance by larger phytoplankton species with a better ability to screen UVB. Thus, improved nutrient status and greater mean cell size could lead to less UVB sensitivity in coastal populations. Differential responses to solar UVA and UVB in coastal waters were observed in photosynthetic carbon fixation by phytoplankton assemblages, with UVB inhibiting all the size fractions and moderate levels of UVA stimulating photosynthesis in cells with diameters $>5 \mu \mathrm{m}$ (Li \& Gao 2013). A study by W. K. W. Li et al. (2009) showed that phytoplankton community structure shifted from micro-dominated to nano- and pico-dominated due to a typhoon event, and back to a micro-dominated again $2 \mathrm{wk}$ after the event. UVR did bring about much higher photosynthetic inhibition in post-typhoon than in pre-typhoon phytoplankton assemblages in the South China Sea coastal water (G. Li et al. 2009). Additionally, these studies provide evidence that larger algal cells in coastal waters possess a better capability to tolerate UVB irradiance, and these larger cells with high levels of MAAs may even benefit from moderate levels of longer wavelength UVA, since some species can utilize UVA for photosynthetic carbon fixation (Gao et al. 2007, G. Li et al. 2009, 2011, Li \& Gao 2013) though MAAs themselves are not able to act as accessory pigments (Inoue et al. 2002).

\section{NUTRIENT-UVB INTERACTIONS}

The effects of UVR on cellular processes may be exacerbated by the combined effect of nutrient limitation on the UVB sensitivity of algae. UVB causes damage to a range of components and processes of cell metabolism, including nucleic acids and Rubisco, with D1and D2 proteins of the Photosystem II (PSII) reaction centre being particularly sensitive (Karentz et al. 1991, Vincent \& Roy 1993, Gieskes \& Buma 1997, Buma et al. 2001a,b).

The net effect of UVR on photosynthesis $(P)$ can be explained by a number of models (Lesser et al. 1994, Neale 2000). The simplest of these is the Kok model in which the net impact is a balance between damage $(k)$, which is a function of the number of remaining targets, and repair $(r)$ :

$$
\frac{P}{P_{\text {initial }}}=\frac{r}{k+r}+\frac{k}{k+r} \mathrm{e}^{-(k+r) t}
$$

When damage exceeds repair capacity, photosynthesis declines exponentially with increased time of exposure. Factors influencing damage and/or repair could therefore interact with UV-induced effects on the physiological performance of algae (Lesser et al. 1994, Heraud \& Beardall 2000, Gao et al. 2008).

Nitrogen (N) limitation could potentially limit the ability of algae to synthesise UV-screening compounds and/or enzymes involved in scavenging of ROS (Beardall et al. 2009a). For example, Figueroa \& Korbee (2010) reported increases in MAAs of 33 to $204 \%$ in a range of red algae grown under high $\mathrm{N}$ compared with low $\mathrm{N}$ conditions. Zheng \& Gao (2009) also showed increased contents of MAAs in a red alga with enriched nitrate levels, leading to lessened UV inhibition of its photosynthesis. Decreased contents of MAAs under $\mathrm{N}$ limitation have also been reported for dinoflagellates with increased UVrelated inhibition (Litchman et al. 2002). In the macroalga Gracilaria lemaneiformis, MAAs increased under solar radiation with UVR and decreased under low indoor light without UVR, regardless of the nutrient levels, while inhibition of both growth and photosynthesis decreased with increased contents of MAAs (Zheng \& Gao 2009). In the same red alga, while UVB and phosphorus (P) limitation acted synergistically to reduce growth and photosynthetic pigments, P limitation did not affect the content of MAAs (Xu \& Gao 2009).

Under $\mathrm{N}$ limitation then, there are 3 scenarios for the potential interactions with UVB: (1) synthesis of UVB screening compounds such as MAAs or of enzymes responsible for photoprotective antioxidant 
scavenging of ROS could be decreased as a consequence of reduced availability of $\mathrm{N}$, so cells are more prone to damage ( $k$ in Eq. 1 increases); or (2) the capacity of cells for repair of damage is diminished as the $\mathrm{N}$ supply for repair of affected proteins is diminished ( $r$ in Eq. 1 decreases); or (3) a combination of scenarios 1 and 2 ( $k$ in Eq. 1 increases and $r$ decreases) (Beardall et al. 2009a).

Data in support of these scenarios is limited mainly to experiments with microalgae. While algae experience high damage under high levels of solar radiation, acclimation to UVR could increase their tolerance, due to increased repair capacity or improved UV screening leading to decreased damage. Although Behrenfeld et al. (1994), working on the diatom Phaeodactylum tricornutum, found no measurable impact of UVB on growth rates and biomass accumulation rates under $\mathrm{N}$ limitation, cells were only exposed to UVB when cultures were well into the stationary phase and metabolic processes such as repair might be expected to already be at a minimum.

Lesser et al. (1994) demonstrated that N-limited phytoplankton were more susceptible to UVR than their nutrient-replete counterparts and suggested that the increase in UVB sensitivity was a consequence of impaired ability to carry out repair under nutrient limitation (scenario 2 above). This was shown in additional experiments using streptomycin, an inhibitor of chloroplast protein synthesis; treatment during exposure to UVB resulted in an increase in photoinhibition as the repair function was eliminated. Experiments reported by Litchman et al. (2002) showed lower rates of damage ( $r$ in Eq. 1) together with lower levels of MAAs (leading to higher $k$ in Eq. 1) in N-limited dinoflagellates, which is consistent with scenario 3 above. However, the above experiments were mostly based on short-term exposure to UVR. Under chronic exposure combined with nutrient $(\mathrm{N})$ limitation, decreased growth rates were not explained by photoinhibition, but appeared to be related to effects on cell division, leading to an increase in cell size (Veen et al. 1997, Buma et al. 2000). N limitation in Dunaliella tertiolecta has been demonstrated to lead not only to an increase in damage (as expected from scenario 1) when cells were exposed to an acute dose of UVB, but also to a stimulation of repair capacity (Shelly et al. 2002). This stimulation of repair though was not sufficient to overcome the inhibition of PSII function by acute UVB exposure, which was still greater in N-limited cultures (Shelly et al. 2002). When grown under chronic UVB exposure, however, D. tertiolecta cultures, although still showing stimulation of repair compared with unexposed cells, underwent a 5-fold decline in the repair constant when they were $\mathrm{N}$ starved for 2 d (Shelly 2005). N starvation thus elicited a different response to UVB than $\mathrm{N}$ limitation under balanced growth, as was achieved in the chemostats used by Shelly et al. (2002).

In Heterocapsa sp., there appear to be 2 modes of photoprotection depending on the N supply. When $\mathrm{N}$ is replete photoprotection involves MAAs, but under $\mathrm{N}$ limitation, the xanthophyll cycle becomes more active (Korbee et al. 2010).

In contrast to the studies on microalgae, there are very few data on the interactions of $\mathrm{N}$ limitation with UVR in macroalgae. In the studies of Zheng \& Gao (2009) reported above, the higher MAA concentrations in Gracilaria lemaneiformis under nitrate enrichment significantly decreased the UV-induced inhibition of growth and photosynthesis. In the same organism, UVB significantly reduced the net photosynthetic rate, but this was alleviated by enrichment with ammonia (which also stimulated the accumulation of UV-absorbing compounds) (Z. Xu \& Gao 2012) Similar data are reported for Porphyra by Korbee et al. (2005) and Barufi et al. (2011). These data and other works cited by Figueroa \& Korbee (2010) imply that low $\mathrm{N}$ availability enhances the UVR sensitivity of photosynthesis and growth of macroalgae, perhaps by decreasing the capacity to minimise damage through MAA synthesis.

The interactions between P levels and UVR effects in natural communities have mainly been investigated in freshwater systems (Harrison \& Smith 2009). Given the major impacts of P limitation on a range of physiological and biochemical processes in algae, it is not surprising that these interact with UVR. However, a priori, it might be expected that $\mathrm{P}$ limitation and the availability of PAR can influence UVB sensitivity by impairing the ability of cells to produce the energy necessary to carry out repair processes ( $r$ decreases; equivalent to scenario 2 for $\mathrm{N}$ limitation above).

Aubriot et al. (2004) suggested that the P status of phytoplankton cells from a coastal lagoon modulated their UVR sensitivity. Inhibition of phosphate uptake by UVR was increased under more P-limited conditions. This was postulated to be due to the impact of UVR on the availability of energy for P uptake, as was shown to be the case for freshwater phytoplankton in Lake Erie (Allen \& Smith 2002). In the red alga Gracilaria lemaneiformis, UV-induced inhibition of photosynthesis and growth was exacerbated under P-limited conditions, but the presence of UVR enhanced the activity of total carbonic anhydrase in 
the thalli and raised the photosynthetic affinity for exogenous inorganic carbon (Xu \& Gao 2009). In contrast, Carrillo et al. (2008) and Korbee et al. (2012) reported that addition of $\mathrm{P}$ to a high mountain lake resulted in enhanced UVR impacts.

The main effect on algal cells of P limitation when interacting with UVB exposure is via energy generation processes. UVB affects PSII electron transport, which in turn causes ATP production to drop and diminish the supply of energy to drive repair of UVBinduced damage. This effect would be exacerbated if the availability of P for ATP synthesis was limited (Beardall et al. 2009a). Furthermore, the major requirement for P in cells is for ribosomal RNA (Flynn et al. 2010) and thus P limitation would also be likely to reduce the capacity for transcription and translation, thereby impairing the enzymatic repair of UVR damage.

Thus, in laboratory cultures of $D$. tertiolecta (Heraud et al. 2005), P starvation led to an increased rate of decline in PSII quantum yield when cells were exposed to UVB, which was paralleled by a decrease in repair rates. Heraud et al. (2005) explained this increased UVB sensitivity as a consequence of an inhibition of repair mechanisms (corresponding to scenario 2 above). Growth limitation by $\mathrm{P}$ without UVB exposure also decreased the repair rates, but the rate at which repair rates decreased as $\mathrm{P}$ starvation proceeded was much greater under UVB exposure. This is consistent with reduced ATP levels in P-starved cultures, though this was not measured during the study.

Other effects of UVB on P status and cellular physiology can be less direct. Thus, Garde \& Gustavson (1999) showed that the effects of UVB on natural phytoplankton under low $\mathrm{P}$ levels were exacerbated by the inhibitory action of UVB on alkalinephosphatase activity (produced by P-limited cells to enhance the utilization of organic P). This means that such organisms will be even more stressed under P-limited conditions if UVB is present.

Interactive effects between P levels and UVR impacts on algae might also be indirect, involving other components of aquatic communities. For instance, in freshwater systems, Xenopoulos \& Bird (1997) have shown that under P-limited conditions, bacteria showed a higher susceptibility to UVR, which in turn reduced competition between bacteria and phytoplankton for $\mathrm{P}$ and thereby increased the availability of $\mathrm{P}$ to phytoplankton. UVR may also increase the availability of $\mathrm{P}$ to phytoplankton by causing photolysis of organic matter and release of $\mathrm{P}$ (Wetzel et al. 1995). UVB radiation alters the biological availability of dissolved organic matter to microorganisms, and accelerates its transformation into dissolved inorganic carbon and nitrogen, including carbon dioxide and ammonium (Piccini et al. 2009, Vähätalo et al. 2011, Mostofa et al. 2013). Such effects may also impact on mixotrophic growth of algae; Laurion et al. (1998) showed that in lake mesocosms, the mixotrophic nanoflagellate Ochromonas grew faster under enhanced UVB, possibly as a result of increased release of organic nutrients for osmotrophy or phagotrophy following enhanced bacterial growth.

Despite the fact that large areas of the world's oceans are characterised by having limiting iron (Fe) concentrations (e.g. see Behrenfeld et al. 1996), almost nothing is known about the interactions of UVR with Fe limitation, though UV-mediated photolysis of Fe-containing molecules appeared to raise $\mathrm{Fe}$ availability to phytoplankton (Barbeau et al. 2001a,b). Fe ions would become more available from binding ligands produced through UV-mediated cell lysis (Barbeau et al. 2001a,b), through the hydrogen peroxide produced due to the interactions between organic matter from cell lysis and UVR is toxic to some phytoplankton species, and this could have substantial effects on phytoplankton communities (Leunert et al. 2014).

Van de Poll et al. (2005) reported that Fe-limited cultures of the Antarctic marine diatom Chaetoceros brevis were less sensitive to high levels of PAR and UVR than Fe-replete cultures, this possibly being associated with elevated levels of ROS scavengers, such as superoxide dismutase and ascorbate peroxidase, in Fe-limited cells (Van de Poll et al. 2009). Clearly more work is required in this area.

A more detailed discussion of the interactions between nutrient supply and UVB is provided by Beardall et al. (2009a).

Thus, the sea-surface warming expected in the future may indirectly, through its impact on nutrient availability, increase UVB sensitivity and decrease primary productivity of the oceans. However, other components of global climate change may have more direct impacts on UVB sensitivity.

\section{TEMPERATURE-UVB INTERACTIONS}

Changes in UVB irradiance are affected not only by changes in the ozone layer, but also by other factors (clouds, air pollution, surface albedo) (McKenzie et al. 2011). Global warming is known to reduce the stratospheric temperature and therefore enhance the depletion of ozone (Häder et al. 2011). 
It might also be expected that organisms in the 2 hemispheres of our planet would experience different environments, due to the fact that the temperate regions in the Northern Hemisphere have a higher thermal amplitude (due to a larger land mass) compared with the Southern Hemisphere, which is composed of more oceanic water (Goncalves et al. 2010). The Northern Hemisphere is thus expected to experience a greater temperature and precipitation increase, compared with the Southern Hemisphere, which, on the other hand, is expected to be more affected by stratospheric ozone dynamics (Goncalves et al. 2010).

Ocean warming is predicted to enhance the stratification process or prolong periods of stratification (especially during summer periods), leading to shoaling of the UML. Therefore marine organisms within the UML might be expected to experience higher UVR fluxes and higher temperatures for a longer period of time (or during different seasons) compared with now) (Goncalves et al. 2010, Helbling et al. 2011). On the other hand, if the UML has a longer residence time, that means that exchange between the UML and deeper water is going to be reduced, which, in turn, can affect nutrients and coloured dissolved organic matter concentration (Goncalves et al. 2010). Such multiple forcings can have combined impacts on phytoplankton - more photodamage with a stimulated repair processes would be expected; however, the stimulation of repair capability due to increased temperature as well as to UVR exposure should lag behind the damage. Such effects might be particularly significant for the Southern Hemisphere (which currently experiences a relatively lower average temperature than the Northern Hemisphere) (Goncalves et al. 2010).

Field studies have revealed that the response of phytoplankton to UVR changes seasonally (Piquet et al. 2010) — phytoplankton are more resistant in summer even though UVR is highest at that time (Wu et al. 2010a, Helbling et al. 2013). It is important to point out that we could expect species-specific as well as complex responses of organisms when it comes to multifactorial experiments (Halac et al. 2010).

We might expect a priori, and with reference to the Kok equation (Eq. 1), that temperature might exert an effect on net UVB impacts by affecting enzymedriven repair mechanisms more than photochemical damage. In the model diatom Phaeodactylum tricornutum, increased temperature did increase the repair rate of PSII either under ambient or elevated $\mathrm{CO}_{2}$ levels in the presence of UVA or UVB (Y. Li et al. 2012). The increased repair to damage ratios inversely correlate with non-photochemical quench- ing, regardless of the temperature levels. This is possibly related to temperature-independent damage caused to PSII (Y. Li et al. 2012). Increased temperature and exposure to UVR increased inhibition of photochemical quantum yield in phytoplankton assemblages from Patagonia in Argentina (Villafañe et al. 2013); however, increased temperature in this region helped to counter the magnitude of daytime yield decrease during the phytoplankton bloom onset (Helbling et al. 2013).

As mentioned previously, UVR can damage organisms on various levels - it can impact on their proteins, pigments, or DNA, which can in turn affect their ability to take up nutrients, move, photosynthesize, or carry out transcription and replication of DNA (Buma et al. 2003). This, in turn, can affect their ability to grow and reproduce.

In photosynthetic organisms, 2 of the main targets for UVR are DNA and photosynthetic apparatus (Buma et al. 2003). Damage to DNA is not irreversible, due to the ability of cells to perform repair processes, if conditions are suitable. One of the pathways by which DNA is repaired is photoreactivation via the enzyme photolyase, which functions under the UVA part of the spectrum (Buma et al. 2003). Repair thus depends on UVA and PAR, so both damage and repair process are light dependent, but the latter might also be temperature dependent, as temperature might increase enzyme performance. In addition, pre-exposure to moderate levels of UVB can also aid in photochemical recovery in darkness (Xu \& Gao 2010 a,b,c). Another type of mechanism is photoprotection, via the production of photoprotective pigments or enhancement of the xanthophyll cycle. In this case, it is not temperature dependent, but MAA production at least is dependent on nutrient availability (Litchman et al. 2002), which means if waters were to experience nutrient limitation, this type of protection against UVR would not fare as well as an enzymatic-based one.

Among aquatic organisms, temperature itself, but interactive effects as well, are expected to have different effects, depending on the type of organism. For example, the response of corals to both elevated UVR and temperature are expected to differ from those of phytoplankton and macroalgae because in this group (corals) the temperature rises experienced generally take organisms above their optimum and thus represent an additional stress, while, on the other hand, it is expected to be beneficial for the other 2 groups in high latitudes (Hoffman et al. 2003).

However, this was only partially true for the 4 corals investigated by Ferrier-Pagès et al. (2007), 
who showed a strong interaction of UVR and temperature in the photoinhibition of zooxanthellae photosynthetic apparatus in 3 of the 4 investigated species under the short-term conditions (exposure to high temperatures for $5 \mathrm{~h}$ only). Two clades $\mathrm{A}$ and 2 clades $\mathrm{C}$ of zooxanthellae were investigated at temperatures ranging from 27 to $34^{\circ} \mathrm{C}$ under both UVA and UVB radiation. At the highest temperature investigated $\left(34^{\circ} \mathrm{C}\right)$, in conjunction with UVR, some species showed up to $50 \%$ reduction in maximum photochemical yield. However, when Ferrier-Pagès et al. (2007) investigated long-term effects (exposure of up to $17 \mathrm{~d}$ ), the drop in maximum yield was evident after day 3 of exposure (with Montipora aequituberculata being the most resistant species with only $13 \%$ reduction, while the other 3 on average had a $24 \%$ reduction), but remained constant until the end of the incubation period. This suggests the presence of a protective mechanism that switches on after $3 \mathrm{~d}$, and keeps being active for a longer period of time. This was indeed the case, as evident from the production of MAAs in all investigated corals (Ferrier-Pagès et al. 2007), with $M$. aequituberculata containing the highest concentration and greater diversity of MAAs. What is evident from this research is that the susceptibility of corals to bleaching depends on previous exposure history and their capacity to up-regulate defence mechanisms (Ferrier-Pagès et al. 2007).

Previous exposure history was also important for the response of Symbiodinium, whereby 4 different Symbiodinium isolates (genotypes) responded differently to acclimation to both temperature and UVR, although acclimation was present in all isolates (Rogers et al. 2010). Pre-acclimation lasted for $14 \mathrm{~d}$ under temperatures ranging from 26 to $32{ }^{\circ} \mathrm{C}$, with acclimation to both low and high light, supplemented with UVR, while growth rates were measured after a further $14 \mathrm{~d}$ of incubation (Rogers et al. 2010). However, only pre-acclimation to different temperatures and UVR induced the acclimatory response, while acclimation to low or high PAR light had no effect. Even though previous exposure to temperature and UVR might reduce coral bleaching, it does not mean that the upper thermal limit is going to be increased as, in some cases, corals form symbiosis with only one Symbiodinium genotype, so in the case of more sensitive genotypes, these won't be replaced with the more tolerant one (Rogers et al. 2010).

Thermal stress affects not only zooxanthellae in the coral community, but also the host, as shown by Lesser \& Farrell (2004). Studies similar to those described above, involving pre-acclimation of organ- isms to various stressors, were carried out with Montastraea faveolata under a range of temperatures $\left(29\right.$ to $\left.32^{\circ} \mathrm{C}\right)$. There was an interactive effect between UVR and elevated temperature on M. faveolata, expressed as an effect on photochemistry and carbon fixation simultaneously and further expressed as increased production of ROS. What is surprising is that there was no accumulation of MAAs under any of the conditions, which might be a consequence of either breakdown of MAAs, or reduced photosynthesis affecting the flow of carbon into the shikimate pathway responsible for MAA production (Lesser \& Farrell 2004). In the case of $M$. faveolata and its symbiont, both experienced cellular damage during the thermal stress that was intensified by UVR (Lesser \& Farrell 2004). Damage occurring in the zooxanthellae was based on effects on photochemistry and carbon fixation, while the host experienced DNA damage, apoptosis or necrosis of the tissue (Lesser \& Farrell 2004).

Elevated temperature is known to be beneficial for cyanobacterial growth (Elliott 2010). The ability of freshwater cyanobacteria to repair damage caused by UVR under thermal stress has been shown to be species-specific, in an experiment with $3 \mathrm{~d}$ acclimation and subsequent $4 \mathrm{~d}$ exposure to 18 and $23^{\circ} \mathrm{C}$ under natural UVR and PAR, obtained by different filter combinations (Giordanino et al. 2011). In these experiments, Anabaena species and Nostoc sp. benefited from elevated temperature, seen as higher recovery rates, compared with Arthrospira platensis and Microcystis sp, which showed no response to elevated temperature. Increased recovery rates were explained by increased metabolic rates, but it is possible that recovery was driven by enzymatic processes, which are expected to benefit from higher temperatures (Buma et al. 2003). Interestingly, increases in temperature negated the effect of elevated UVR on morphological changes in Anabaena sp. and Nostoc sp. (Giordanino et al. 2011), while higher temperatures led to less DNA damage and a lower percentage of spiral breakage in the economically important cyanobacterium A. platensis (Gao et al. 2008). In contrast, in coastal marine phytoplankton assemblages from the South China Sea, UV-induced inhibition of photosynthetic carbon fixation was less during summer than during winter periods in spite of higher levels of incident UV irradiance and temperature (Wu et al. 2010a). It is most likely that elevated temperature enhanced enzymatic synthesis or activity so that repair processes became stimulated.

When investigating the opposite effect, that of low temperature, in freshwater systems in Antarctica, 
Roos \&Vincent (1998) found that lower temperature reduced the ability of a freshwater cyanobacterium (Phormidium murrayi) to repair damage caused by UVR. Phormidium sp. was grown at temperatures ranging from 5 to $25^{\circ} \mathrm{C}$ under artificial UVR and PAR over $5 \mathrm{~d}$. Effects on photosynthetic properties showed a time delay between $t_{0}$ and $5 \mathrm{~d}$ later, implying that a dose-dependent response is involved. Reduction in temperature was marked by reduced growth rates under elevated UVR, although growth rates under moderate UVR conditions increased over time, implying the ability of cells to gradually acclimate to the UVR exposure, including by an observed increase in ROS-quenching carotenoids. This is particularly important because many environments, e.g. at high latitudes or high elevation, that experience very low temperatures also experience elevated UVR at the same time, making them susceptible to any interactive effects between these factors. Even if future climate change brings about an increase in average temperature, as predicted, regions in the Southern Hemisphere are not going to experience the same level of temperature increase as Northern Hemisphere regions (Goncalves et al. 2010).

A positive effect of elevated temperature when interacting with UVR was evident in the diatom Thalassiosira pseudonana, where growth rates increased under elevated temperature, while chlorophyll per cell and maximum photosynthesis $\left(P_{\max }\right)$ did not, but there was a high temperature dependence of primary production in cells exposed to UVR (Sobrino \& Neale 2007). This is consistent with elevated temperature improving enzymatic activity involved in the repair process (Buma et al. 2003, Sobrino \& Neale 2007). Sensitivity of $T$. pseudonana to UVR decreased under elevated temperature, while the opposite effect was evident at lower temperatures $\left(15^{\circ} \mathrm{C}\right.$ in this case). This effect was mostly pronounced under short-term conditions (pre-acclimated cultures at $20^{\circ} \mathrm{C}$ subsequently exposed to 15 or $25^{\circ} \mathrm{C}$ for 10 min prior to taking measurements), but persisted to some extent under long-term conditions as well (1 wk at 15, 20, and $25^{\circ} \mathrm{C}$ ) (Sobrino \& Neale 2007). Short- and longterm experiments differed in changes to damage and repair rates, where complex processes were responsible for the long-term response, while under short-term conditions changes in repair and damage occurred at a similar rate (Sobrino \& Neale 2007).

Effects of fast (short-term) changes in temperature were investigated in another diatom, Phaeodactylum tricornutum, which showed a similar response whereby a 'greenhouse' treatment of increased temperature with high $\mathrm{CO}_{2}$ resulted in better photo- synthetic performance and reduced sensitivity to UVR compared with cells grown in ambient conditions (Y. Li et al. 2012). This treatment, however, included elevated $\mathrm{CO}_{2}$, in addition to elevated temperature, whereby the high $\mathrm{CO}_{2}$ levels reduced the inhibition of photosynthesis caused by UVR (Y. Li et al. 2012).

Though one of the most common mechanisms that phytoplankton use when dealing with increased UVR is increased repair, it is only one of many strategies. For instance, a diatom, Thalassiosira weissflogii, was shown to increase its Rubisco activity and gene expression as a consequence of an increase of $5^{\circ} \mathrm{C}$ (from 20 to $25^{\circ} \mathrm{C}$ ) over a period of 2 wk (Helbling et al. 2011). This enables this particular species to achieve a higher rate of light processing with less need for excess energy dissipation, which was evident in the higher effective quantum yield and lower levels of non-photochemical quenching (a measure of energy dissipation) (Helbling et al. 2011). Compared with other mechanisms recorded as ways used by diatoms for dealing with increased UVR (higher repair rates in Thalassiosira pseudonana and energy dissipation in Chaetoceros gracilis) (Sobrino \& Neale 2007, Halac et al. 2010), whereby energy would be used for processes other than production, increasing Rubisco activity actually promotes higher photosynthetic rates and biomass accrual of this species (Helbling et al. 2011). If this was translated to the community level, it means that species that are using this type of mechanism to deal with elevated UVR and temperature would be well positioned to outcompete others that rely on repair processes only, causing a shift in species composition.

The community structure of phytoplankton is likely to be affected by the interactive effects between temperature and UVR, but is also dependent on other environmental factors. Using an example from freshwater systems, when investigating high-latitude lake phytoplankton, UVR was shown to inhibit growth more at $6^{\circ} \mathrm{C}$ than at $14^{\circ} \mathrm{C}$ (Doyle et al. 2005), although this response was dependent on the species investigated and nutrients present. Thus a diatom, Fragilaria sp., was the species most affected at $14^{\circ} \mathrm{C}$ under elevated UVR conditions, but only under nutrientreplete conditions, due to higher growth rates (attributable to a high nutrient load and higher temperature), because under these conditions DNA synthesis was accelerated and more prone to UVR damage than under less favourable conditions (Doyle et al. 2005).

Studies of UVR effects on macroalgae have focused more on their early developmental stages than on 
fully formed thalli, and the interaction of UVR with temperature shows changes at certain threshold temperatures (Hoffman et al. 2003). Thus, germination of propagules in the kelp Fucus gardneri was strongly affected by the interaction between temperature and UVR, whereby germination increased by $30 \%$ at the highest temperature of $20^{\circ} \mathrm{C}$ (in the absence of UVR), but with the addition of UVR, temperature had no effect on germination at all. On the other hand, germination at 2 lower temperatures $\left(10\right.$ and $\left.15^{\circ} \mathrm{C}\right)$ was strongly affected by both temperature and UVR (Hoffman et al. 2003). A similar response was observed in Gelidium pulchellum grown at 15 and $25^{\circ} \mathrm{C}$, whereby the high-temperature-grown thalli showed a less marked change in quantum yield, $F_{\mathrm{v}} / F_{\mathrm{m}}$, under UVR, compared with the low-temperature algae (Gomez et al. 2001).

The sensitivity of macroalgae to UVR is very much species-specific, but also depends on their developmental stage. Thus different Fucus species showed different sensitivity to UVB, with $F$. serratus germlings being completely killed by UVB of $0.8 \mathrm{~W} \mathrm{~m}^{-2}$, F. vesiculosus less so (90\% of germilings killed off), while $F$. spiralis had $>50 \%$ survival rate under the same conditions (Altamirano et al. 2003). At the same time, F. serratus showed the highest sensitivity to the interactive effects of UVB and temperature, as some repair mechanisms were less efficient at higher temperatures. Based on the response of all species and interactive effects, Altamirano et al. (2003) concluded that macroalgal growth is less sensitive to UVB at lower temperatures, and such speciesspecific responses to these environmental factors might affect zonation of different species along the shore. Altamirano et al. (2003) also showed differences in response between UVA and UVB effects. The lowest relative growth rates of germlings were always recorded in PAR plus UVA plus UVB (PAB) treatments, and were the highest in a 'PAR only' treatment, with UVA plus PAR having an intermediate response, but the UVR levels causing the effects differed between different Fucus species at all temperatures investigated. Two macroalgal species, Saccharina latissima and Laminaria digitata, also also showed differential responses between different stages of their life cycle (Müller et al. 2008). Thus, zoospore formation (gametogenesis) in L. digitata was positively affected by UVA, and was more affected under elevated temperature. On the other hand, egg release and sporophyte formation in another brown alga, L. hyperborea, was impaired by UVA, even at favourable temperatures (Müller et al. 2008). In contrast, gametogenesis in these spe- cies was shown to be UVB tolerant, irrespective of the temperature. Müller et al. (2008) thus showed species-specific and stage-specific responses among macroalgae to the damage-repair balance at various temperatures. Under natural diel temperature changes, the conchocelis phase of Porphyra haitainensis showed much lower levels of diurnal effective quantum yield compared with its vegetative thallus stage (Jiang et al. 2008), and sheltering in shells provided significant protection from UVR for the conchocelsis (Jiang et al. 2009). Species successional changes were associated with a decline in UVR sensitivity of macroalgal communities after 2 to 3 mo in different regions across both hemispheres (Wahl et al. 2004). Different latitudes with different temperature, diel, and seasonal variations, along with different macroalgal communities, can lead to differential effects of UVR.

\section{UVR-CO ${ }_{2}$ INTERACTIONS}

Increasing atmospheric $\mathrm{CO}_{2}$ and its dissolution into seawater is known to alter marine carbonate chemistry, causing OA. The literature on the effects of OA on both phytoplankton and macroalgae is rapidly growing, but the effects reported are very varied. Some papers report stimulative effects, others show neutral, and some show inhibitory impacts on photosynthesis, growth, or other physiological parameters (see the reviews of Riebesell \& Tortell 2011 and Gao et al. 2012a, and literature therein). Such different responses reported so far have even been reported for the same species or strain (Gao \& Campbell 2014). There have been few studies on the effects of OA under multiple stressors and evolutionary responses in marine primary producers. However, it is generally accepted that OA due to increased $p \mathrm{CO}_{2}$ downregulates carbon-concentrating mechanisms (CCMs) and alters the differential responses to OA under different light levels, at least in diatoms.

A large number of marine and freshwater primary producers express CCMs (Giordano et al. 2005, Beardall et al. 2009b), which are modulated by a range of environmental factors, including elevated $\mathrm{CO}_{2}$ concentrations (Giordano et al. 2005). The presence or absence of CCMs in a particular species might influence their response to future climate change scenarios, including both increased $\mathrm{CO}_{2}$ availability (and consequent seawater acidity) and increased UVB irradiance. CCMs are energetically costly, and their down-regulation can save the energy that would be diverted to other physiological pro- 
cesses in cells (including mechanisms to minimise or repair damage; see Eq. 1), so that growth or other physiological processes may respond differentially to UVR under elevated $\mathrm{CO}_{2}$ and lower $\mathrm{pH}$ conditions (OA scenario) (Gao et al. 2012b). This can be further complicated by differential sensitivity to UVB of the mechanisms involved in carbon acquisition - as $\mathrm{CO}_{2}$ or $\mathrm{HCO}_{3}{ }^{-}$(Sobrino et al. 2005). In the diatom Phaeodactylum tricornutum, OA treatment and UVB showed antagonistic effects, resulting in fast photochemical recovery and a higher repair/damage ratio in the OA-grown cells (Y. Li et al. 2012). On the other hand, OA and UVB acted synergistically to reduce calcification of the algal calcifiers Emiliania huxleyi (Gao et al. 2009) and Coralina sessilis (Gao \& Zheng 2010). Under fluctuating sunlight, however, UVB was shown to have little impact on cells grown under OA conditions (Jin et al. 2013). To predict the performance of primary producers exposed to the combined influence of UVR and $\mathrm{CO}_{2}$, species-specific physiological traits are important and should be investigated under different experimental setups.

Algal uptake and utilization of inorganic carbon is facilitated by the presence of carbonic anhydrase (CA), which controls reversible $\mathrm{CO}_{2}-\mathrm{HCO}_{3}{ }^{-}$interchange, and is an important factor in functioning CCMs. Moderate levels of both UVA and UVB have been shown to promote CA activity and periplasmic protein synthesis, with moderate levels of UVA and UVB treatments increasing CA activity by 28 and $24 \%$, respectively, in the diatom Skeletonema costatum (Wu \& Gao 2009). UVA and UVB are known to damage DNA or proteins; however, moderate levels of UVA have also been shown to stimulate photosynthetic carbon fixation of phytoplankton assemblages (Gao et al. 2007, Li et al. 2011) and enhance growth of a red alga (Gao et al. 2008). Apparently, UVA irradiance can modulate CCMs or photosynthetic inorganic carbon affinity in both diatoms (Wu \& Gao 2009) and macroalgae (Xu \& Gao 2009). It is likely that UVR can act antagonistically with elevated levels of $\mathrm{CO}_{2}$ that down-regulate CCMs (Gao et al. 2012a).

Research on the interactive effects of elevated $\mathrm{CO}_{2}$ and UVR has been increasing in recent years. In most cases, research has focused on the effects these factors have on growth and photosynthetic performance, with little attention given to explaining the exact CCM mechanisms involved (Beardall et al. 2009b). In contrast to CCM down-regulation or complete switch-off under very high $\mathrm{CO}_{2}$ levels (10 000 to 50000 ppmv) (see review by Giordano et al. (2005) and literature therein), recent studies have shown that elevated levels of $\mathrm{CO}_{2}$ up to that predicted for the end of this century (1000 ppmv) have been shown to down-regulate CCMs in diatoms (Wu et al. 2010b, W. Li et al. 2012, Yang \& Gao 2012). While most of these results were obtained under PAR-alone conditions, there have been a few studies that examined the algae grown under solar radiation in the presence of UVR at elevated $\mathrm{CO}_{2}$ (Xu \& Gao 2009, Chen \& Gao 2011, Wu et al. 2012). When the diatom Cylindrotheca closterium f. minutissima was grown under natural solar radiation for $6 \mathrm{~d}$, its growth rate was little affected by elevated $\mathrm{CO}_{2}$ and no obvious correlation with the radiation dose (for both PAR and PAR + UV treatments) could be detected. However, the relative electron transport rate was reduced and was more sensitive to UVR in the cells maintained at elevated $\mathrm{CO}_{2}$ compared with the cells grown at ambient $\mathrm{CO}_{2}$, with the CCM being down-regulated (Wu et al. 2012). In the red alga Gracilaria lemaneiformis, when grown under natural solar radiation at ambient $\mathrm{CO}_{2}$ levels, the presence of UVR enhanced the activity of total CA and the photosynthetic affinity for exogenous inorganic carbon (Gao \& Xu 2008, Xu \& Gao 2009). In the diatom $S$. costatum, during the induction of periplasmic (extracellular) CA activity under reduced $\mathrm{CO}_{2}$ availability at $\mathrm{pH} 8.7$, exposure to moderate levels of UVA and/or UVB for 1 to $2 \mathrm{~h}$ enhanced CA activity and its synthesis (Wu \& Gao 2009). These results imply that UVR and $\mathrm{CO}_{2}$ can interact to influence the CCMs in these algal species. However, such an interaction might be species-specific. In the red tide alga Phaeocystis globosa, the CCM was not affected by elevated $p \mathrm{CO}_{2}$ and $\mathrm{UVR}$, in view of unchanged activities of both intracellular and extracellular CA and non-responsive photosynthetic affinity with $\mathrm{CO}_{2}$ enrichment (Chen \& Gao 2011). The interactive effects of UVR and $\mathrm{CO}_{2}$ on algal CCMs could be neutral or antagonistic, which could also be dependent on levels of solar radiation.

UVR affected the assimilation of inorganic carbon in the green alga Dunaliella tertiolecta, but not the uptake of carbon, which resulted in an increased intracellular pool of inorganic carbon under elevated UVR conditions (Beardall et al. 2002). This was explained by the differential effect that UVR had on PSI, compared with PSII, the latter being more prone to damage under UVR conditions. Cyclic electron flow around PSI drives ATP production (necessary for CCM activity). On the other hand, PSII, which is more affected by UVR, is required for non-cyclic electron flow (together with PSI), generating both ATP and NADPH, as needed for assimilation of carbon. However, UV-stimulated carbon acquisition might be partially responsible 
if transmembrane ion channels are responsive to UV irradiances.

When observing the interactive effects of these 2 parameters, the lack of interaction could be influenced by different targets for each factor individually, so the combined effect would be expected to be additive, but based on the initial results that was not the case (Beardall et al. 2009a).

Early results obtained on the interactive effects of UVR and $\mathrm{CO}_{2}$ and OA showed this to be very much dependent on the species, which was influenced by their preference for the species of inorganic carbon used (Sobrino et al. 2005). Studies on Nannochloris and Nannochloropsis species, with different CCM mechanisms, showed that this interaction can either be non-existent or positive. No interaction between UVR and OA was present in Nannochloris atomus, which is a $\mathrm{CO}_{2}$ user: even though increased $\mathrm{CO}_{2}$ positively influenced its growth and photosynthesis rates, addition of UVR did not impact on the sensitivity of this species. In contrast, in Nannochloropsis gaditana, which is known to transport $\mathrm{HCO}_{3}{ }^{-}$, elevated $\mathrm{CO}_{2}$ decreased not only the growth rate, but also the sensitivity to UVR (Sobrino et al. 2005). Such different responses from species could affect the composition of communities and their combined response to this interaction.

Increased growth and photosynthesis under elevated $\mathrm{CO}_{2}$ does not necessarily mean that they are also going to improve the sensitivity of a particular species to UVR, as shown for Thalassiosira pseudonana (Sobrino et al. 2008). These authors recognized the need to properly acclimate cultures to elevated $\mathrm{CO}_{2}$ levels prior to UVR exposure, and argued that some of the effects observed in the earlier study by Sobrino et al. (2005) could be due to differences in the acclimation period. As mentioned above in relation to temperature, the acclimation period is important in some species to properly understand their response to elevated UVR. In the case of the diatom T. pseudonana, acclimation of cells to high $\mathrm{CO}_{2}$ (1000 ppmv) caused a higher sensitivity to UVR, compared with the cells acclimated to ambient atmospheric $\mathrm{CO}_{2}$ levels. Similar to the need for $\mathrm{CO}_{2}$ acclimation, it was shown that acclimation to UVR diminishes the increase in susceptibility experienced under elevated $\mathrm{CO}_{2}$ levels, reflecting an antagonistic effect (Sobrino et al. 2008). At the same time, increased susceptibility of T. pseudonana to UVR under elevated $\mathrm{CO}_{2}$ was explained by down-regulation of the photosynthetic apparatus under those conditions, which in turn affects the repair mechanism and enzymes involved (Sobrino et al. 2008). On the other hand, in the same species, when grown under similar $\mathrm{CO}_{2}$ levels (representing the OA scenario) and exposed to extremely high PAR levels $\left(1200 \mu \mathrm{mol}\right.$ photons $\left.\mathrm{m}^{-2} \mathrm{~s}^{-1}\right)$, down-regulation of CCMs by high $\mathrm{CO}_{2}$ did not cause any additional light stress in this species, as evident by the same response of photochemical and non-photochemical quenching under different $\mathrm{CO}_{2}$ levels (Yang \& Gao 2012). When grown under ambient $\mathrm{CO}_{2}$ concentrations, a strain of the diatom $S$. costatum that had been grown under indoor low light without UV for decades increased its tolerance of UVR compared with that of a wild strain (freshly isolated from the ocean) in terms of growth rate, after acclimation for $3 \mathrm{~d}$ to natural solar radiation with UVR (Guan \& Gao 2008). Nevertheless, light history or evolutionary adaptation (as can happen with strains grown in a laboratory for decades) could result in differential photosynthetic and growth responses of phytoplankton to UVR and/ or OA. It is increasingly important to use freshly isolated species from different waters to examine the effects of OA or/and UVR.

The interactive effects of $\mathrm{CO}_{2}$ and UVR would be particularly important in assessing the performance of some algae of concern, such as those, both toxic or non-toxic, that form blooms (Gao et al. 2012a). For instance, P. globosa showed both negative (reduced rates under elevated $\mathrm{CO}_{2}$ and PAR or total solar radiation) or positive (stimulation of photochemical yield and growth rate by UVA and $\mathrm{CO}_{2}$ during cloudy days) effects (Chen \& Gao 2011). Furthermore, there were different effects of UVA and UVB in the study of Chen \& Gao (2011): UVA acted synergistically with elevated $\mathrm{CO}_{2}$ to increase photosynthetic performance; however, a reduction in photochemical efficiency (effective quantum yield) and growth was caused by the synergistic effects of UVB and acidification, while moderate levels of UVA stimulated both parameters. Due to the opposite effects of UVA and UVB in combination with $\mathrm{CO}_{2}$ (acidification), the future response of primary producers and the balanced effect of acidification may depend on the depth at which organisms are found (due to differences in UVA and UVB penetration with depth).

Emiliania huxleyi, a coccolithophore known to form extensive blooms in both the Northern and Southern hemispheres, was also investigated for similar synergistic effects. This species forms external plates (coccoliths) made out of $\mathrm{CaCO}_{3}$, via a mechanism that includes various species of inorganic carbon. Hence, elevated $\mathrm{CO}_{2}$ levels might affect both photosynthesis and calcification in this species, although, as pointed out by Doney et al. (2009) and others (see Beardall et al. 2009b), responses vary widely between strains 
and experimental approach. Gao et al. (2009) exposed this alga, grown under elevated $\mathrm{CO}_{2}$, to UVR and found that reduced thickness of the coccolith layers led to higher inhibition of photosynthesis. On the other hand, reduction of the $\mathrm{Ca}^{2+}$ level by 100 fold did not affect $E$. huxleyi's growth but reduced its non-photochemical quenching, reflecting a role of calcification as an additional energy sink for photoprotection (K. Xu \& Gao 2012). These 2 processes, calcification and non-photochemical quenching, might be linked to protect the cells from photodamage. The calcified layer of coccoliths in E. huxleyi was shown to screen off about $25 \%$ of UVB (Gao et al. 2009). When this alga was grown under elevated dissolved inorganic carbon levels, the thickness of coccolith cover increased, with reduced photochemical sensitivity to UVR (Guan \& Gao 2010a,b). This suggests that calcification can optically shield off UVR and decrease damage caused by photoinhibition.

Not just individual species of phytoplankton, but also communities have been investigated for the interactive effects of UVR and $\mathrm{CO}_{2}$. For instance, in the USA, Lake Giles phytoplankton responded positively to the addition of $\mathrm{CO}_{2}$, showing an increase in their productivity of up to $23 \%$ (Sobrino et al. 2009). However, with the addition of $\mathrm{CO}_{2}$, this population was also more susceptible to UVR, as $\mathrm{CO}_{2}$ increased their sensitivity and photoinhibition. This was true, irrespective of the $\mathrm{CO}_{2}$ treatment applied-whether it was artificial addition of $\mathrm{CO}_{2}$ or by mineralization of coloured dissolved organic matter (CDOM) derived from the terrestrial environment. The effect of CDOM is particularly interesting, as it has been shown that the availability of inorganic elements, such as carbon, nitrogen and iron, can be raised in the presence of UVR that enhances the photolysis of CDOMs (Mostofa et al. 2013). Full understanding of the performance of natural populations is difficult, due to a range of other environmental factors that might be having an impact at the same time (Sobrino et al. 2009).

One would expect that marine macroalgae would be even more affected by OA and UVR, due to their ecological niche. Ulva lactuca is an intertidal green macroalga that is exposed to varying $\mathrm{CO}_{2}$ and UVR levels during a tidal cycle. When exposed to air during low tide under different $\mathrm{CO}_{2}$ levels, mimicking intertidal conditions, this species showed stimulated photosynthetic rates at the elevated $\mathrm{CO}_{2}$ level, but extended exposures around noon in the presence of UVR caused photoinhibition (Zou et al. 2007). The red alga Gracilaria lemaneiformis grown under elevated $\mathrm{CO}_{2}$ eliminated the deleterious effects of UVR on photosynthesis by increasing the content of UVRabsorbing compounds and maintaining high contents of phycoerythrin (Xu \& Gao 2010a,b), while for another red macroalga, Porphyra haitanensis, UVR offset the benefit from elevated levels of $\mathrm{CO}_{2}$ to its growth (Xu \& Gao 2013).

When trying to evaluate more than 2 parameters that are going to change under future climate change scenarios, the response gets even more complicated. For instance, the diatom Phaeodactylum tricornutum was tested by Y. Li et al. (2012) for the combined effects of elevated $\mathrm{CO}_{2}$ (as ocean acidification), UVR, and temperature. They showed that elevated $\mathrm{CO}_{2}$ levels countered the harmful effects of UVR on PSII by stimulating non-photochemical quenching, but this was less evident under elevated temperature. On the other hand, temperature and $\mathrm{CO}_{2}$ acted in synergy by reducing the inhibition in carbon fixation rate caused by UVR (Y. Li et al. 2012). While diatoms grown under elevated $\mathrm{CO}_{2}$ levels of 800 to 1000 ppmv showed enhanced photorespiration and non-photochemical quenching (Gao et al. 2012a), which play photoprotective roles, elevated levels of $\mathrm{CO}_{2}$ could possibly enhance photosynthetic carbon fixation even in the presence of UVR, counteracting the negative effects of seawater acidification and associated chemical changes.

\section{CONCLUSIONS AND FUTURE RESEARCH PERSPECTIVES}

It is clear that other factors (temperature, nutrient availability, elevated $\mathrm{CO}_{2}$ and $\mathrm{OA}$ ) associated with global change will have an effect on the susceptibility of algal photosynthesis and growth to UVR as summarised in Fig. 2. Importantly it seems that many of these factors can tip the balance between damage and repair processes, which defines the net impact of UVR. The key points are:

- UVB is one of the key climate change multiple stressors, and increasing irradiance or exposure with global warming (due to a shoaled UML) can interact with other environmental factors or stressors to influence marine primary producers, though different waters or species show differential responses.

- Reduced availability of inorganic nitrogen increases the sensitivity of algae to UVR, but there is some variability in the effects of phosphate limitation on the response of algae to UVR, which merits further investigation.

- There are major gaps in our understanding - there are large species-specific differences in responses to 


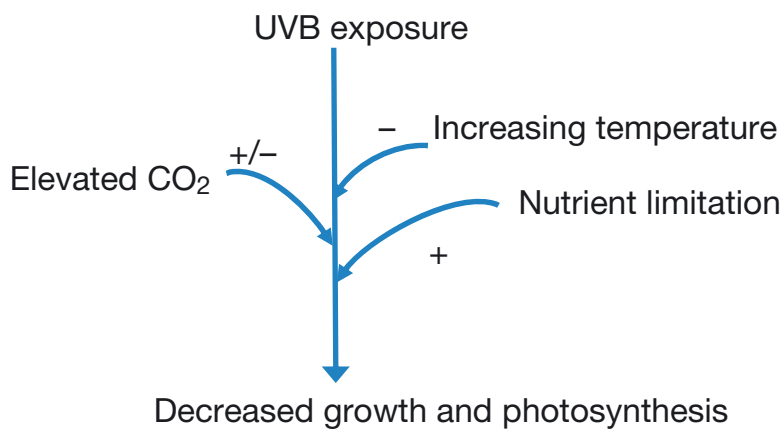

Fig. 2. Schematic of the effects of other environmental factors associated with global change (temperature, nutrient limitation, elevated $\mathrm{CO}_{2}$ and $\mathrm{OA}$ ) on the inhibition of algal growth and photosynthesis by UVB. +: stimulation of inhibition, -: reduction in inhibition. Note that in some circumstances, UVA (not shown) can cause a stimulation rather than an inhibition of physiological performance. Effects on \#morphology are not shown

UVR and its interactions with other stressors, as well as time-dependent effects that depend on the degree of acclimation. Furthermore, only a few species of algae and aquatic macrophytes have so far been investigated.

- There is a lack of information on how iron limitation might influence UVB susceptibility, which is of especial interest given the large proportion of the world ocean (especially in the Pacific and Southern oceans) that is impacted by low iron concentrations.

- If the world's oceans in tropical and mid-latitudes are likely to become more nutrient-limited, with an increased dominance of smaller-celled organisms, attention needs to be given to species that are likely to become more dominant (such as Prochlorococcus or nanophytoplankton).

- While a number of reports in the literature document the impacts of UVR on the relationship between photosynthesis and growth with light, little is known on how UVR affects thermal windows (physiological parameters vs. temperature) of algae.

- While nutrient availability affects the tolerance of algae to UVR, elevated $\mathrm{CO}_{2}$ and OA could counteract some of the effects induced by UVR. However, the mechanisms involved are unclear.

As a final note, we point out that it is important to consider the time course of experiments designed to investigate interactions of UVR with other stressors, as short-term experiments can potentially ignore longer-term acclimation responses. There is also much to be learnt from field-based experiments; for example, studies of OA effects on algae surrounding volcanic $\mathrm{CO}_{2}$ vents, such as those conducted by Porzio et al. (2011) and Johnson et al. (2012), have provided useful information on OA impacts and could be extended to look at UVR-OA interactions. Finally, studies of interactions among a range of environmental factors (UV, $\mathrm{CO}_{2}$, temperature, nutrients) require careful attention to the experimental design, whether these studies are laboratory- or field-based.

\section{LITERATURE CITED}

Allen CD, Smith REH (2002) The response of planktonic phosphate uptake and turnover to ultraviolet radiation in Lake Erie. Can J Fish Aquat Sci 59:778-786

Altamirano M, Flores-Moya A, Figueroa FL (2003) Effects of UV radiation and temperature on growth of germlings of three species of Fucus (Phaeophyceae). Aquat Bot 75: 9-20

> Aubriot L, Conde D, Bonilla S, Sommaruga R (2004) Phosphate uptake behavior of natural phytoplankton during exposure to solar ultraviolet radiation in a shallow coastal lagoon. Mar Biol 144:623-631

> Bakun A (1990) Global climate change and intensification of coastal ocean upwelling. Science 247:198-201

Barbeau K, Rue EL, Bruland KW, Butler A (2001a) Photochemical cycling of iron in the surface ocean mediated by microbial iron(III)-binding ligands. Nature 413:409-413

Barbeau K, Kujawinski EB, Moffett JW (2001b) Remineralization and recycling of iron, thorium and organic carbon by heterotrophic marine protists in culture. Aquat Microb Ecol 24:69-81

Barufi JB, Korbee N, Oliviera MC, Figueroa FL (2011) Effects of $\mathrm{N}$ supply on the accumulation of photosynthetic pigments and photoprotectors in Gracilaria tenuistipitata (Rhodophyta) cultured under UV radiation. J Appl Phycol 23:457-466

Beardall J, Raven JA (2004) The potential effects of global climate change on microalgal photosynthesis, growth and ecology. Phycologia 43:26-40

Beardall J, Heraud P, Roberts S, Shelly K, Stojkovic S (2002) Effects of UV -B radiation on inorganic carbon acquisition by the marine microalga Dunaliella tertiolecta (Chlorophyceae). Phycologia 41:268-272

> Beardall J, Sobrino C, Stojkovic S (2009a) Interactions between the impacts of ultraviolet radiation, elevated $\mathrm{CO}_{2}$ and nutrient limitation on marine primary producers. Photochem Photobiol Sci 8:1257-1265

Beardall J, Stojkovic S, Larsen S (2009b) Living in a high $\mathrm{CO}_{2}$ world: impacts of global climate change on marine phytoplankton. Plant Ecol Divers 2:191-205

Beaufort L, Probert I, de Garidel-Thoron T, Bendif EM and others (2011) Sensitivity of coccolithophores to carbonate chemistry and ocean acidification. Nature 476:80-83

> Behrenfeld MJ, Lee H, Small LF (1994) Interactions between nutritional status and long-term responses of ultraviolet$B$ radiation stress in a marine diatom. Mar Biol 118: 523-530

Behrenfeld MJ, Bale AJ, Kolber ZS, Aiken J, Falkowski PG (1996) Confirmation of iron limitation of phytoplankton photosynthesis in the equatorial Pacific Ocean. Nature 383:508-511

> Bischof K, Gómez I, Molis M, Hanelt D and others (2006) Ultraviolet radiation shapes seaweed communities. Rev Environ Sci Biotechnol 5:141-166

Boyd PW, Hutchins DA (2012) Understanding the responses of ocean biota to a complex matrix of cumulative anthro- 
pogenic change. Mar Ecol Prog Ser 470:125-135

Buma AGJ, van Oijen T, van de Poll W, Veldhuis MJW, Gieskes WWL (2000) The sensitivity of Emiliania huxleyi (Prymnesiophyceae) to ultraviolet-b radiation. J Phycol 36:296-303

Buma AGJ, Helbling EW, de Boer MK, Villafane VE (2001a) Patterns of DNA damage and photoinhibition in temperate South-Atlantic picophytoplankton exposed to solar ultraviolet radiation. J Photochem Photobiol B 62:9-18

> Buma AGJ, de Boer MK, Boelen P (2001b) Depth distributions of DNA damage in Antarctic marine phyto- and bacterioplankton exposed to summertime UV radiation. J Phycol 37:200-208

Buma AGJ, Boelen P, Jeffrey WH (2003) UVR-induced DNA damage in aquatic organisms. In: Helbling EW, Zagarese $\mathrm{H}$ (eds) UV effects in aquatic organisms and ecosystems. The Royal Society of Chemistry, Springer-Verlag, Cambridge, p 291-328

> Carreto JI, Carignan M (2011) Mycosporine-like amino acids: relevant secondary metabolites. Chemical and ecological aspects. Mar Drugs 9:387-446

> Carrillo P, Delgado-Molina JA, Medina-Sánchez JM, Bullejos FJ, Villar-Argaiz M (2008) Phosphorus inputs unmask negative effects of ultraviolet radiation on algae in a high mountain lake. Glob Change Biol 14:423-439

> Chen S, Gao K (2011) Solar ultraviolet radiation and $\mathrm{CO}_{2}$ induced ocean acidification interacts to influence the photosynthetic performance of the red tide alga Phaeocystis globosa (Prymnesiophyceae). Hydrobiologia 675: 105-117

Chisholm SW (1992) Phytoplankton size. In: Falkowski PG, Woodhead AD (eds) Primary productivity and biogeochemical cycles in the sea.Plenum Press, New York, NY, p 213-237

Coale KH, Johnson KS, Fitzwater SE, Gordon RM and others (1996) A massive phytoplankton bloom induced by an ecosystem-scale iron fertilization experiment in the equatorial Pacific Ocean. Nature 383:495-501

Doney SC (2006) The dangers of ocean acidification. Sci Am 294:58-65

> Doney SC, Fabry VJ, Feely RA, Kleypas JA (2009) Ocean acidification: the other $\mathrm{CO}_{2}$ problem. Annu Rev Mar Sci 1:169-192

> Doney SC, Ruckelshaus M, Duffy JE, Barry JP and others (2012) Climate change impacts on marine ecosystems. Annu Rev Mar Sci 4:11-37

> Doyle SA, Saros JE, Williamson CE (2005) Interactive effects of temperature and nutrient limitation on the response of alpine phytoplankton growth to ultraviolet radiation. Limnol Oceanogr 50:1362-1367

> Elliott A (2010) The seasonal sensitivity of cyanobacteria and other phytoplankton to changes in flushing rate and water temperature. Glob Change Biol 16:864-876

Engel A (2002) Direct relationship between $\mathrm{CO}_{2}$ uptake and transparent exopolymer particles production in natural phytoplankton. J Plankton Res 24:49-53

Engel A, Thoms S, Riebesell U, Rochelle-Newall E, Zondervan I (2004) Polysaccharide aggregation as a potential sink for marine dissolved organic carbon. Nature 428: 929-932

> Eppley RW, Peterson BJ (1979) Particulate organic matter flux and planktonic new production in the deep ocean. Nature 282:677-680

> Feely RA, Doney SC, Cooley SR (2009) Present conditions and future changes in a high- $\mathrm{CO}_{2}$ world. Oceanography
(Wash DC) 22:36-47

Ferrier-Pagès C, Richard C, Forcioli D, Allemand D, Pichon M, Shick JM (2007) Effects of temperature and UV radiation increases on the photosynthetic efficiency in four scleractinian coral species. Biol Bull 213:76-87

Figueroa FL, Gómez I (2001) Photosynthetic acclimation to solar UV radiation of marine red algae from the warm temperate coast of southern Spain: a review. J Appl Phycol 13:233-245

Figueroa FL, Korbee NN (2010) Interactive effects of UV radiation and nutrients on ecophysiology: vulnerability and adaptation to climate change. In: Israel A, Einav R, Seckbach J (eds) Seaweeds and their role in globally changing environments. Cellular origin, life in extreme habitats and astrobiology, Vol. 15. Springer, Dordrecht, p 157-182

Figueroa FL, Jiménez C, Viñegla B, Pérez-Rodríguez E and others (2002) Effects of solar radiation in the marine angiosperm Posidonia oceanica from southern Spain. Mar Ecol Prog Ser 230:59-70

Finkel ZV (2007) Does phytoplankton cell size matter? The evolution of modern marine food webs. In: Falkowski PG, Knoll AH (eds) Evolution of aquatic photoautotrophs. Academic Press, San Diego, CA, p 333-350

> Finkel ZV, Beardall J, Flynn KJ, Quigg A, Rees RAV, Raven JA (2010) Phytoplankton in a changing world: cell size and elemental stoichiometry. J Plankton Res 32:119-137

> Flores-Moya A, Hanelt D, Figueroa FL, Altamirano M, Viñegla B, Salles S (1999) Involvement of solar UVB radiation in recovery of inhibited photosynthesis in the brown alga Dictyota dichotoma (Hudson) Lamoroux. J Photochem Photobiol B 49:129-135

> Flynn KJ, Raven JA, Rees TAV, Finkel ZV, Quigg A, Beardall J (2010) Is the growth rate hypothesis applicable to microalgae? J Phycol 46:1-12

Gao K, Campbell DA (2014) Photophysiological responses of marine diatoms to elevated $\mathrm{CO}_{2}$ and decreased $\mathrm{pH}$ : a review. Funct Plant Biol 41:449-459

Gao K, Xu J (2008) Effects of solar UV radiation on diurnal photosynthetic performance and growth of Gracilaria lemaneiformis (Rhodophyta). Eur J Phycol 43:297-307

Gao K, Zheng Y (2010) Combined effects of ocean acidification and solar UV radiation on photosynthesis, growth, pigmentation and calcification of the coralline alga Corallina sessilis (Rhodophyta). Glob Change Biol 16: 2388-2398

Gao K, Wu Y, Li G, Wu H, Villafañe VE, Helbling EW (2007) Solar UV radiation drives $\mathrm{CO}_{2}$ fixation in marine phytoplankton: a double-edged sword. Plant Physiol 144:54-59

> Gao K, Li P, Watanabe T, Helbling EW (2008) Combined effects of ultraviolet radiation and temperature on morphology, photosynthesis, and DNA of Arthrospira (Spirulina) platensis (Cyanophyta). J Phycol 44:777-786

Gao K, Ruan Z, Villafane VE, Gattuso JP, Helbling EW (2009) Ocean acidification exacerbates the effect of UV radiation on the calcifying phytoplankter Emiliania huxleyi. Limnol Oceanogr 54:1855-1862

Gao K, Helbling EW, Häder DP, Hutchins DA (2012a) Responses of marine primary producers to interactions between ocean acidification, solar radiation, and warming. Mar Ecol Prog Ser 470:167-189

Gao K, Xu J, Gao G, Li Y and others (2012b) Rising $\mathrm{CO}_{2}$ and increased light exposure synergistically reduce marine primary productivity. Nat Clim Change 2:519-523

Garcia-Pichel F (1994) A model for internal self-shading in 
planktonic organisms and its implications for the usefulness of ultraviolet sunscreens. Limnol Oceanogr 39: 1704-1717

Garde K, Gustavson K (1999) The impact of UVB radiation on alkaline phosphatase activity in phosphorus-depleted marine ecosystems. J Exp Mar Biol Ecol 238:93-105

Gieskes WWC, Buma AGJ (1997) UV damage to plant life in a photobiologically dynamic environment: the case of marine phytoplankton. Plant Ecol 128:17-25

Giordanino MVF, Strauch SM, Villafañe VE, Helbling EW (2011) Influence of temperature and UVR on photosynthesis and morphology of four species of cyanobacteria. J Photochem Photobiol B 103:68-77

Giordano M, Beardall J, Raven JA (2005) $\mathrm{CO}_{2}$ concetrating mechanisms in algae: mechanisms, environmental modulation, and evolution. Annu Rev Plant Biol 56:99-131

Goffart A, Heco JH, Legendre L (2002) Changes in the development of the winter-spring phytoplankton bloom in the Bay of Calvi (NW Mediterranean) over the last two decades: a response to changing climate? Mar Ecol Prog Ser 236:45-60

Gomez I, Figueroa FL, Sousa-Pinto I, Vinegla B, Pérez P (2001) Effects of UV radiation and temperature on photosynthesis as measured by PAM fluorescence in the red alga Gelidium pulchellum (Turner) Kutzing. Bot Mar 44: 9-16

Goncalves RJ, Souza MS, Aigo J, Modenutti B, Balseiro E, Villafañe VE, Cussac V, Helbling EW (2010) Responses of plankton and fish and temperate zones to UVR and temperature in a context of global change. Ecología Austral 20:129-153

Guan W, Gao K (2008) Light histories influence the impacts of solar ultraviolet radiation on photosynthesis and growth in a marine diatom, Skeletonema costatum. J Photochem Photobiol B 91:151-156

> Guan W, Gao K (2010a) Impacts of UV radiation on photosynthesis and growth of the coccolithophore Emiliania huxleyi (Haptophyceae). Environ Exp Bot 67:502-508

Guan W, Gao K (2010b) Enhanced calcification ameliorates the negative effects of UV radiation on photosynthesis in the calcifying phytoplankter Emiliania huxleyi. Chin Sci Bull 55:588-593

Häder DP, Sinha RP (2005) Solar ultraviolet radiationinduced DNA damage in aquatic organisms: potential environmental impact. Mutat Res-Fund Mol M 571: 221-233

> Häder DP, Kumarb HD, Smithc RC, Worrest RC (2007) Effects of solar UV radiation on aquatic ecosystems and interactions with climate change. Photochem Photobiol Sci 6:267-285

> Häder DP, Helbling EW, Williamson CE, Worrest RC (2011) Effects of UV radiation on aquatic ecosystems and interactions with climate change. Photochem Photobiol Sci 10:242-260

> Halac SR, Villafañe VE, Helbling EW (2010) Temperature benefits the photosynthetic performance of the diatoms Chaetoceros gracilis and Thalassiosira weissflogii when exposed to UVR. J Photochem Photobiol B 101:196-205

Hanelt D, Roleda MY (2009) UVB radiation may ameliorate photoinhibition in specific shallow-water tropical marine macrophytes. Aquat Bot 91:6-12

Hanelt D, Hawes I, Rae R (2006) Reduction of UV-B radiation causes an enhancement of photoinhibition in high light stressed aquatic plants from New Zealand lakes. J Photochem Photobiol B 84:89-102
Harrison JW, Smith REH (2009) Effects of ultraviolet radiation on the productivity and composition of freshwater phytoplankton communities. Photochem Photobiol Sci 8: 1218-1232

Hegglin MI, Shepherd TG (2009) Large climate-induced changes in ultraviolet index and stratospheric-totroposphere ozone flux. Nat Geosci 2:687-691

Helbling EW, Gao KS, Goncalves RJ, Wu HY, Villafane VE (2003) Utilization of solar UV radiation by coastal phytoplankton assemblages off SE China when exposed to fast mixing. Mar Ecol Prog Ser 259:59-66

> Helbling EW, Buma AGJ, Boelen P, Van der Strate HJ, Giordanino MVF, Villafañe VE (2011) Increase in Rubisco activity and gene expression due to elevated temperature partially counteracts ultraviolet radiation-induced photoinhibition in the marine diatom Thalassiossira weissflogii. Limnol Oceanogr 56:1330-1342

> Helbling EW, Banaszak AT, Villafañe VE (2013) Differential responses of two phytoplankton communities from the Chubut River Estuary (Patagonia, Argentina) to the combination of UVR and elevated temperature. Estuaries Coasts, doi:10.1007/s12237-013-9752-7

> Heraud P, Beardall J (2000) Changes in chlorophyll fluorescence during exposure of Dunaliella tertiolecta to UV radiation indicate a dynamic interaction between damage and repair processes. Photosynth Res 63:123-134

Heraud P, Roberts S, Shelly K, Beardall J (2005) Interactions between UVB exposure and phosphorus nutrition. II. Effects, on rates of damage and repair. J Phycol 41: 1212-1218

Hoffman JR, Hansen LJ, Klinger T (2003) Interactions between UV radiation and temperature limit inferences from single-factor experiments. J Phycol 39:268-272

Hutchins DA (2011) Forecasting the rain ratio. Nature 476: 41-42

Iglesias-Rodriguez MD, Halloran PR, Rickaby REM, Hall IR and others (2008) Phytoplankton calcification in a high $\mathrm{CO}_{2}$ world. Science 320:336-339

Inoue Y, Hori H, Sakurai T, Tokimoto Y, Saito J, Misonou T (2002) Measurement of fluorescence quantum yield of ultraviolet-absorbing substance extracted from red alga: Porphyra yezoensis and its photothermal spectroscopy. Opt Rev 9:75-80

Jiang H, Gao K, Helbling EW (2007) Effects of solar UV radiation on germination of conchospores and morphogenesis of sporelings in Porphyra haitanensis (Rhodophyta). Mar Biol 151:1751-1759

- Jiang H, Gao K, Helbling EW (2008) UV-absorbing compounds in Porphyra haitanensis (Rhodophyta) with special reference to effects of desiccation. J Appl Phycol 20: 387-395

Jiang H, Gao K, Helbling EW (2009) The conchocelis of Porphyra haitanensis (Rhodophyta) is protected from harmful UV radiation by the covering calcareous matrix. J Phycol 45:1270-1277

> Jin P, Gao K, Villafañe VE, Campbell DA, Helbling W (2013) Ocean acidification alters the photosynthetic responses of a coccolithophorid to fluctuating UV and visible radiation. Plant Physiol 162:2084-2094

> Johnson VR, Russell BD, Fabricius KE, Brownlee C, HallSpencer JM (2012) Temperate and tropical brown macroalgae thrive, despite decalcification, along natural $\mathrm{CO}_{2}$ gradients. Glob Change Biol 18:2792-2803

Karentz D, Cleaver JE, Mitchell DL (1991) Cell survival characteristics and molecular responses of Antarctic 
phytoplankton to ultraviolet-B radiation. J Phycol 27: 326-341

- Key T, McCarthy A, Campbell DA, Six C, Roy S, Finkel ZV (2010) Cell size trade-offs govern light exploitation strategies in phytoplankton. Environ Microbiol 12: 95-104

Korbee N, Huovinen P, Figueroa F, Aguilera J, Karsten U (2005) Availability of ammonium photosynthesis and the accumulation of mycosporine-like amino acids in two Porphyra species (Bangiales, Rhodophyta). Mar Biol 146: 645-654

Korbee N, Mata MT, Figueroa FL (2010) Photoprotection mechanisms against ultraviolet radiation in Heterocapsa sp. (Dinophyceae) are influenced by nitrogen availability: mycosporine-like amino acids vs. xanthophyll cycle. Limnol Oceanogr 55:899-908

Korbee N, Carrillo P, Mata MT, Rosillo S, Medina-Sánchez JM, Figueroa FL (2012) Effects of ultraviolet radiation and nutrients on the structure-function of phytoplankton in a high mountain lake. Photochem Photobiol Sci 11: 1087-1098

> Langer MR, Geisen M, Baumann KH, Kläs J, Riebesell U, Thoms S, Young JR (2006) Species-specific responses of calcifying algae to changing seawater carbonate chemistry. Geochem Geophys Geosyst 7:Q09006, doi:10.1029/ 2005GC001227

Laurion I, Vincent WF (1998) Cell size versus taxonomic composition as determinants of UV-sensitivity in natural phytoplankton communities. Limnol Oceanogr 43: 1774-1779

Laurion I, Lean DRS, Vincent WF (1998) UVB effects on a plankton community: results from a large-scale enclosure assay. Aquat Microb Ecol 16:189-198

> Lesser MP, Farrell JH (2004) Exposure to solar radiation increases damage to both host tissues and algal symbionts of corals during thermal stress. Coral Reefs 23:367-377

> Lesser MP, Cullen JJ, Neale PJ (1994) Carbon uptake in a marine diatom during acute exposure to ultraviolet $\mathrm{B}$ radiation: relative importance of damage and repair. J Phycol 30:183-192

> Leunert F, Eckert W, Paul A, Gerhardt V, Grossart HP (2014) Phytoplankton response to UV-generated hydrogen peroxide from natural organic matter. J Plankton Res 36: 185-197

> Li G, Gao K (2013) Cell size-dependent effects of solar UV radiation on primary production in coastal waters of the South China Sea. Estuaries Coasts 36:728-736

Li G, Wu Y, Gao K (2009) Effects of Typhoon Kaemi on coastal phytoplankton assemblages in the South China Sea, with special reference to the effects of solar UV radiation. J Geophys Res 114:G04029, doi:10.1029/2008 JG000896

> Li G, Gao K, Gao G (2011) Differential impacts of solar UV radiation on photosynthetic carbon fixation from the coastal to offshore surface waters in the South China Sea. Photochem Photobiol 87:329-334

Li G, Che Z, Gao K (2013) Photosynthetic carbon fixation by tropical coral reef phytoplankton assemblages: a UVR perspective. Algae 28:281-288

Li W, Gao K, Beardall J (2012) Interactive effects of ocean acidification and nitrogen-limitation on the diatom Phaeodactylum tricornutum. PLoS ONE 7:e51590

Li WKW, McLaughlin FA, Lovejoy C, Carmack EC (2009) Smallest algae thrive as the Arctic Ocean freshens. Science 326:539
Li Y, Gao K, Villafañe VE, Helbling EW (2012) Ocean acidification mediates photosynthetic response to UV radiation and temperature increase in the diatom Phaeodactylum tricornutum. Biogeosciences 9:3931-3942

> Litchman E, Neale PJ, Banaszak AT (2002) Increased sensitivity to ultraviolet radiation in nitrogen-limited dinoflagellates: photoprotection and repair. Limnol Oceanogr 47:86-94

MacIntyre HL, Kana TM, Geider RJ (2000) The effect of water motion on short-term rates of photosynthesis by marine phytoplankton. Trends Plant Sci 5:12-17

McKenzie RL, Aucamp PJ, Bais AF, Björn LO, Ilyas M, Madronich S (2011) Ozone depletion and climate change: impacts on UV radiation. Photochem Photobiol Sci 10:182-198

Meehl GA, Stocker TF, Collins WD, Friedlingstein P and others (2007) Global climate projections. In: Solomon S, Qin D, Manning M, Chen Z and others (eds) Climate change 2007: the physical science basis. Contribution of Working Group I to the Fourth Assessment Report of the Intergovernmental Panel on Climate Change. Cambridge University Press, Cambridge, p 749-845

Mostofa KMG, Liu CQ, Vione D, Gao K, Ogawa H (2013) Sources, factors, mechanisms and possible solutions to pollutants in marine ecosystems. Environ Pollut 182: 461-478

Müller R, Wiencke C, Bischof K (2008) Interactive effects of UV radiation and temperature on microstages of Laminariales (Phaeophyceae) from the Arctic and North Sea. Clim Res 37:203-213

Neale PJ (2000) Spectral weighting functions for quantifying the effects of ultraviolet radiation in marine ecosystems. In: De Mora SJ, Demers S, Vernet M (eds) Effects of $\mathrm{UV}$ radiation on the marine environment. Cambridge University Press, Cambridge, p 73-100

> Orr JC, Fabry VJ, Aumont O, Bopp L and others (2005) Anthropogenic ocean acidification over the twenty-first century and its impact on calcifying organisms. Nature 437:681-686

Pachauri RK, Reisinger A (eds) (2007) Climate change 2007: synthesis report. Contribution of Working Groups I, II and III to the Fourth Assessment Report of the Intergovernmental Panel on Climate Change. IPCC, Geneva

Pérez-Rodríguez E, Gómez I, Figueroa FL (1998) Effects of $\mathrm{UV}$ radiation on photosynthesis and excretion of UVabsorbing pigments of Dasycladus vermicularis (Chlorophyta, Dasycladales) from Southern Spain. Phycologia 37:379-387

Pérez-Rodríguez E, Aguilera J, Gómez I, Figueroa FL (2001) Excretion of coumarins by the Mediterranean green alga Dasycladus vermicularis in response to environmental stress. Mar Biol 139:633-639

> Piccini C, Conde D, Pernthaler J, Sommaruga R (2009) Alteration of chromophoric dissolved organic matter by solar UV radiation causes rapid changes in bacterial community composition. Photochem Photobiol Sci 8:1321-1328

Piquet AMT, Bolhuis H, Davidson AT, Buma AGJ (2010) Seasonal succession and UV sensitivity of marine bacterioplankton at an Antarctic coastal site. FEMS Microbiol Ecol 73:68-82.

> Pomeroy LR (1974) The ocean's food web, a changing paradigm. Bioscience 24:499-504

Porzio L, Buia MC, Hall-Spencer JM (2011) Effects of ocean acidification on macroalgal communities. J Exp Mar Biol Ecol 400:278-287 
Quintano E, Ganzedo U, Diez I, Figueroa FL, Gorostiaga JM (2013) Solar radiation (UVA and PAR) and water temperature in relation to biochemical performance of Gelidium corneum (Gelidiales, Rhodophyta) in subtidal bottoms off the Basque coast. J Sea Res 83:47-55

Rabalais NN, Turner RE, Dortch Q, Justic V, Bierman VJ, Wiseman WJ (2002) Nutrient-enhanced productivity in the northern Gulf of Mexico: past, present and future. Hydrobiologia 475/476:39-63

Raven JA (1991) Responses of aquatic photosynthetic organisms to increased solar UVB. J Photochem Photobiol B 9: 239-244

Riebesell U, Tortell PD (2011) Effects of ocean acidification on pelagic organisms and ecosystems. In: Gattuso JP, Hansson L (eds) Ocean acidification. Oxford University Press, Oxford, p 99-121

Riebesell U, Revill UAT, Holfsworth DG, Volkman JK (2000) The effect of varying $\mathrm{CO}_{2}$ concentration on lipid composition and carbon isotope fractionation in Emiliania huxleyi. Geochim Cosmochim Acta 64:4179-4192

Rogers JE, Marcovich DT, Jordan SJ, Gallaher SN (2010) Does temperature and UV exposure history modulate the effects of temperature and UV stress on Symbiodinium growth rates? Bull Mar Sci 86:743-761

Roos JC, Vincent WF (1998) Temperature dependence of UV radiation effects on Antarctic cyanobacteria. J Phycol 34: 118-125

Shelly K (2005) Interactions between UVB radiation and nutrient-limitation in a marine microalga. PhD thesis, Monash University, Clayton

Shelly K, Heraud P, Beardall J (2002) Nitrogen limitation in Dunaliella tertiolecta Butcher (Chlorophyceae) leads to increased susceptibility to damage by ultraviolet-B radiation but also increased repair capacity. J Phycol 38: 713-720

Six C, Finkel ZV, Irwin AJ, Campbell DA (2007) Light variability illuminates niche-partitioning among marine picocyanobacteria. PLoS ONE 2:e1341.

Smith CR, Berelson W, Demaster DJ, Dobbs FC and others (1997) Latitudinal variations in benthic processes in the abyssal equatorial Pacific: control by biogenic particle flux. Deep-Sea Res II 44:2295-2317

Sobrino C, Neale PJ (2007) Short-term and long-term effects of temperature on photosynthesis in the diatom Thalassiosira pseudonana under UVR exposures. J Phycol 43: $426-436$

Sobrino C, Neale PJ, Lubián LM (2005) Interaction of UV radiation and inorganic carbon supply in the inhibition of photosynthesis: spectral and temporal responses of two marine picoplankters. Photochem Photobiol 81:384-393

Sobrino C, Ward ML, Neale PJ (2008) Acclimation to elevated carbon dioxide and ultraviolet radiation in the diatom Thalassiosira pseudonana: effects on growth, photosynthesis, and spectral sensitivity of photoinhibition. Limnol Oceanogr 53:494-505

> Sobrino C, Neale PJ, Phillips-Kress JD, Moeller RE, Porterc JA (2009) Elevated $\mathrm{CO}_{2}$ increases sensitivity to ultraviolet radiation in lacustrine phytoplankton assemblages. Limnol Oceanogr 54:2448-2459

Taguchi S (1976) Short-term variability of photosynthesis in natural marine phytoplankton populations. Mar Biol 37: 197-207

> Vähätalo AV, Aarnos H, Hoikkala L, Lignell R (2011) Photochemical transformation of terrestrial dissolved organic matter supports hetero- and autotrophic production in coastal waters. Mar Ecol Prog Ser 423:1-14

Van de Poll WH, van Leeuwe MA, Roggeveld J, Buma AGJ (2005) Nutrient limitation and high irradiance reduce PAR and UV-induced viability loss in the Antarctic diatom Chaetoceros brevis. J Phycol 41:840-850

Van de Poll WH, Janknegt PJ, van Leeuwe MA, Visser RJW, Buma AGJ (2009) Excessive irradiance and antioxidant responses of an Antarctic marine diatom exposed to iron limitation and to dynamic irradiance. J Photochem Photobiol B 94:32-37

Veen A, Reuvers M, Roncak P (1997) Effects of acute and chronic UVB exposure on a green alga: a continuous culture study using a computer-control dynamic light regime. Plant Ecol 128:29-40

Villafañe V, Sundbäck K, Figueroa F, Helbling E (2003) Photosynthesis in the aquatic environment as affected by UVR. In: Helbling EW, Zagarese H (eds) UV effects in aquatic organisms and ecosystems. Royal Society of Chemistry, Cambridge, p 357-397

> Villafañe VE, Banaszak AT, Guendulain-García SD, Strauch SM, Halac SR, Helbling EW (2013) Influence of seasonal variables associated with climate change on photochemical diurnal cycles of marine phytoplankton from Patagonia (Argentina). Limnol Oceanogr 58:203-214

Vincent WF, Belzile C (2003) Biological UV exposure in the polar oceans: Arctic-Antarctic comparisons. In: Huiskes AHL, Gieskes WWC, Rozema J, Schorno RML, van der Vies SM, Wolff WJ (eds) Antarctic biology in a global context. Backhuys Publishers, Leiden, p 176-181

Vincent WF, Neale PJ (2000) Mechanisms of UV damage to aquatic organisms. In: Mora S, Demers S, Vernet M (eds) The effect of UV radiation in the marine environment. Cambridge University Press, Cambridge, p 149-176

Vincent WF, Roy S (1993) Solar ultraviolet-B radiation and aquatic primary production: damage, protection, and recovery. Environ Rev 1:1-12

Viñegla B, Segovia M, Figueroa FL (2006) Effect of artificial $\mathrm{UV}$ radiation on carbon and nitrogen metabolism in the macroalgae Fucus spiralis L. and Ulva olivascens Dangeard. Hydrobiologia 560:31-42

- Wahl M, Molis M, Davis A, Dobretsov S and others (2004) UV effects that come and go: a global comparison of marine benthic community level impacts. Glob Change Biol 10:1962-1972

> Watanabe S, Sudo K, Nagashima T, Takemura T, Kawase H, Nozawa T (2011) Future projections of surface UV-B in a changing climate. J Geophys Res 116:5249-5257

- Wetzel RG, Hatcher PG, Bianchi TS (1995) Natural photolysis by ultraviolet irradiance of recalcitrant dissolved organic matter to simple substrates for rapid bacterial metabolism. Limnol Oceanogr 40:1369-1380

Wiencke C, Gomez I, Pakker H, Flores-Moya A and others (2000) Impact of UV radiation on viability, photosynthetic characteristics and DNA of brown algal zoospores: implications for depth zonation. Mar Ecol Prog Ser 197:217-229

> Williamson CE, Zepp RG, Lucas RM, Madronich S and others (2014) Solar ultraviolet radiation in a changing climate. Nat Clim Change 4:434-441

> Wu H, Gao K (2009) Ultraviolet radiation stimulated activity of extracellular carbonic anhydrase in the marine diatom Skeletonema costatum. Funct Plant Biol 36:137-143

Wu H, Gao K, Villafañe VE, Watanabe T, Helbling EW (2005) Effects of solar UV radiation on morphology and photosynthesis of the filamentous cyanobacterium Arthrospira platensis. Appl Environ Microbiol 71:5004-5013 
Wu X, Gao G, Giordano M, Gao K (2012) Growth and photosynthesis of a diatom grown under elevated $\mathrm{CO}_{2}$ in the presence of solar UV radiation. Fund Appl Limnol 180: 279-290

Wu Y, Gao K, Li G, Helbling EW (2010a) Seasonal impacts of solar UV radiation on photosynthesis of phytoplankton assemblages in the coastal waters of the South China Sea. Photochem Photobiol 86:586-592

Wu Y, Gao K, Riebesell U (2010b) $\mathrm{CO}_{2}$-induced seawater acidification affects physiological performance of the marine diatom Phaeodactylum tricornutum. Biogeosciences 7:2915-2923

Xenopoulos MA, Bird DF (1997) Effect of acute exposure to hydrogen peroxide on the production of phytoplankton and bacterioplankton in a mesohumic lake. Photochem Photobiol 66:471-478

Xu J, Gao K (2010a) UV-A enhanced growth and UV-B induced positive effects in the recovery of photochemical yield in Gracilaria lemaneiformis (Rhodophyta). J Photochem Photobiol B 100:117-122

Xu J, Gao K (2010b) Use of UV-A energy for photosynthesis in the red macroalga Gracilaria lemaneiformis. Photochem Photobiol 86:580-585

$\mathrm{Xu} \mathrm{J}$, Gao K (2010c) The influence of carbon dioxide and solar UVR on the growth, photosynthesis and pigments contents of Gracilaria lemaneiformis. Acta Oceanol Sin 32:144-151 (in Chinese with English Absract)

Submitted: January 31, 2014; Accepted: June 12, 2014
$\mathrm{Xu}$ JT, Gao K (2013) Co-effects of $\mathrm{CO}_{2}$ and solar UVR on the growth and photosynthetic performance of the economic red macroalga Porphyra haitanensis. Acta Oceanol Sin 35:184-190 (in Chinese with English Abstract)

Xu K, Gao K (2012) Reduced calcification decreases photoprotective capability in the coccolithophorid Emiliania huxleyi. Plant Cell Physiol 53:1267-1274

Xu Z, Gao K (2009) Impacts of UV radiation on growth and photosynthetic carbon acquisition in Gracilaria lemaneiformis (Rhodophyta) under phosphorus-limited and replete conditions. Funct Plant Biol 36:1057-1064

$>\mathrm{Xu} \mathrm{Z}$, Gao K (2012) $\mathrm{NH}_{4}{ }^{+}$enrichment and UV radiation interact to affect the photosynthesis and nitrogen uptake of Gracilaria lemaneiformis (Rhodophyta). Mar Pollut Bull 64:99-105

Yang G, Gao K (2012) Physiological responses of the marine diatom Thalassiosira pseudonana to increased $\mathrm{pCO}_{2}$ and seawater acidity. Mar Environ Res 79:142-151

Zheng Y, Gao K (2009) Impacts of solar UV radiation on the photosynthesis, growth and UV-absorbing compounds in Gracilaria lemaneiformis (Rhodophyta) grown at different nitrate concentrations. J Phycol 45:314-323

> Zou DH, Gao KS, Run ZX, Run ZX (2007) Daily timing of emersion and elevated atmospheric $\mathrm{CO}_{2}$ concentration affect photosynthetic performance of the intertidal macroalga Ulva lactuca (Chlorophyta) in sunlight. Bot Mar 50:275-279

Proofs received from author(s): September 23, 2014 